\title{
Decrease of the Suwa Lake Area and Flood Damage
}

久保田稔** 茂吉雅典*** 中村義秋****

\section{by Minoru KUBOTA Masanori MOYOSHI Yoshiaki NAKAMURA}

\section{概 要}

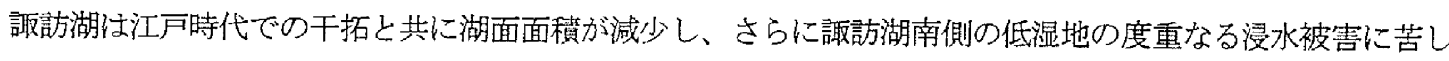
んできた。骤訪湖沿岸部での浸水被害を軽減するために、江戸・明治時代に、湖尻（釡口）の開削を行いさらに 浸水被害住民と製系工場側との話し合いによって、浸水被害も徐々に少なくなって来た。

ところが昭和の時代に入り、西天竜一貫水路建設に端を発し、湖尻を境に、上・下流域住民さらに天竜川を 挟んだ竜西と竜東側の下流住民の間にも争いが発生した。この争いを鎮めた大きな一歩が釜口水門建設である。

本論では、浸水被害状況を1983（昭和５８）年の「58多害」より概観した後に、諏訪湖湖面面積の減少 と大正年代での浸水被害の減少を図より概観する。

1.はじめに 現在、䯅訪湖湖面の面積は $13.3 \mathrm{Km}^{2}$ で、 骤訪湖の流域面積 $527.3 \mathrm{Km}^{2}$ の約 $2.5 \%$ であるが、中世垻 までの諏訪湖は水梁も現在の約 $7 \mathrm{~m}$ よりも染く、面䅡も現在 の2倍近くあったと推測されている。つまり、奈良時代 (710 〜84）以前には、現在の上・下誀訪地域を始好湖周辺の低地 ほほとんど水中に没しており、わずかに鎌倉時代（1185〜 1333）の1329（嘉暦4）年頃に、高島城付近の湖中の小 島が高島と呼ばれ漁村として生計が営まれていたようである。

本論では、高島城の建設と八ヶ岳山麓の開発、排水のため の湖尻（釜口）の開削およひ諏訪湖沿岸部の住民と製系業者 との軒䡯に触れた後、1911（明治44）年加ら1976

（昭和5 1）年までの諏訪湖表面積の変僄について述べ、洪 水被害の減少および釜口水門建設に至った経緯に付いて触れ る。

\section{2 . 近年の浸水状況}

諏訪湖は、後ほど 3 章で述べるように、江戸時代には支川 から流出した土砂の堆積や人為的に行われた埋め立て等に起 因寸る貯水容量の娍少とそれに起因卞る汇濫、明治侍代には天 竜川沿いの製糸業の動力用水車利用による流水の堤上げ、製系 工場の燃料とするための山林乱伐に起因する山の保水力低下 による出水の増加、さらに西天童一蕒水路八の灌激用水供給問 題に起因した西天竜取水堰問題等、きさにその時代の社会状況 と共に多くの問題を起こしてきた。

*keyword : 諏訪湖浸水、湖面積の減少、釜口水門

**正会員 工博 大同工業大学都市環境デザイン学科

(广６11-6111 名古屋市南区白水町40番地)

***正会員 工博 大同工業大学電子情報工学科

河川環境管理財団名古屋支社 元業務課長
ここではまず、明治時代の浸水状況を推測する一助として、 1983 (昭和5 8) 年に諏訲湖沿岸部で発生した淇水被害 について触れておこう。

（1） 1983 年9月の台風 10 号

諏訪地方では、1981（昭和56) 年7月、82年8月 と浸水被害が連続して発生している。ここでは1983（昭 和5 8) 年の「58苂害」について触れよう。1983年9 月19日9時にトラック島付近の海上に発生した弱熱帯低 気圧は徐々に発達し、28日以降に台風10 号方ら温帯低気 圧となり長野県全域に大雨を降らせた。天童狭水位锥測所の 記録によると、1961 (昭和36) 年6月の36災（推定 值 $20.26 \mathrm{~m}$ ）に次ぐ $19.67 \mathrm{~m}$ の水位となり、諏訪地方でよ 1961 年6月洪水の降雨量 $378 \mathrm{~mm}$ に次ぐ 2 日間連続雨 量が $216 \mathrm{~mm}$ の記録的な大豪雨となった。

䯅訪湖人流入する各支川の增水のため、28日午後9時で の諏訪湖人の流入流量は $768 \mathrm{~m}^{3} / \mathrm{s}$ 、一方釜口水門加らの 流出流量仗 $287 \mathrm{~m}^{3} / \mathrm{s}$ で、骤湖湖の水位 (標高 758 . 0 $45 \mathrm{~m} 0 \mathrm{~m}$ とする）は36災の2. 53 mに次ぐ 2.41 $\mathrm{m}$ となった。あふれれた湖水は湖岸を浸水し、浸水家屋 363 7 戸のうち、床上浸水沬諏訪市の家屋全体の $23 \%$ に当たる 1600 F余り、浸水による被害を受けた耕地面稫は諏訪市

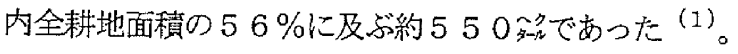


図梳、1983 年台風 10 号による諏訪湖浸水の図である。 諏訪湖周辺と特に低湿地带である南部の豊田、文出、中金子 等いわゆる「克出で村々」地域は完全に浸水しており、わず かに高島公園付近だけが浸水を免れている。

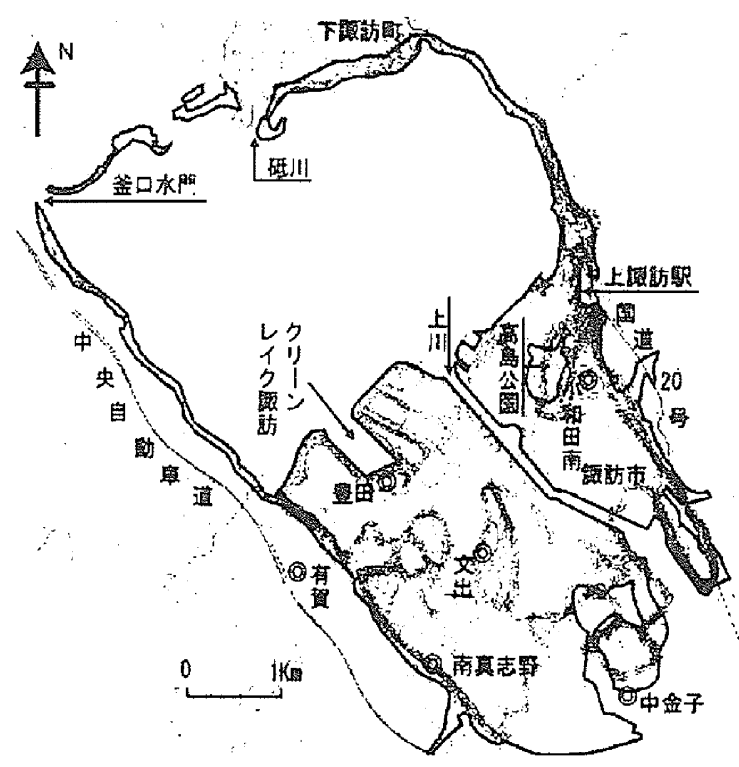

図一1 諏訪湖浻岸部での昭和 58 年10号台風によ る浸水図（長野県土木部諏訪建設事務所製作の諏訪湖 周辺浸水実績図より昭和 58 年の浸水面穦を抽出・加 筆)

この豪雨による特筆すべき災害筍所は、角間川の土石流出、 唐沢川、千本木川、砥川、音無川、湯川、桧沢川、前島川、 宫川の汇濫、福沢山腹の崩壊、細久保、桑原の崖崩れ等であ る。

(2) 宮川での災害

ここで宮川での災害につい述べよう。八ヶ岳と入笠山を 源流とする宮川は、1982年夏の決燷に続き、83年の台風 10 号によって、5ヶ所の堤防が決壊している。この決壊を 契機に、県は宮川を洪水対策の重要河川として、諏訪湖畔半， 木川河口より新井地籍迄の延長 $7295 \mathrm{~m}$ の河川改修と災害

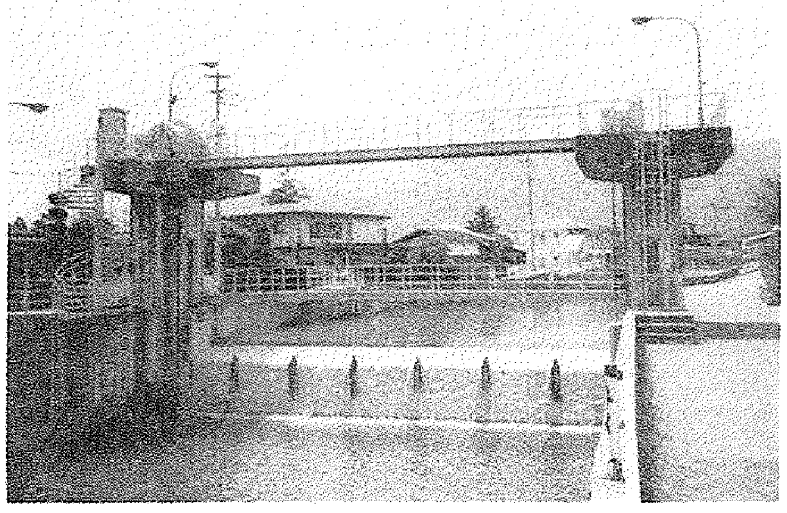

写真-1「文出大堨」。左岸堰柱の所に昭和 24 年の水 神が祀られている。(撮影：久保田、2000年7月 27 日)
復旧による移車家屋 33 月 (636 名)、潰地総面積 34200 $\mathrm{Km}^{2}$ 、橋梁 14 橋、旧宫川の親水公園化、親水公園 2 ヶ所の 新設、支流西沢川の改修等を、災害発生後の 5 年間で行って いる。

この宮川には、高島藩の頃より千石堰と㭔ばれ下流域 13

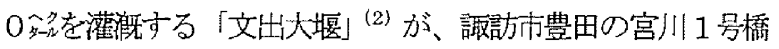
下流10m にある。この堰は、藩の款合地带に灌溉用水を供 給する重要な殹であったが、低地のために洪水被害を度々受 け、人々は恒久的な施設の建設を熱望していた。1948 (昭 和2 3）年6月の台風による被害での揠の改良後、1983 年の台風で再び被害を受け、「大堰」は1988年に、幅約I $5 \mathrm{~m}$ の本川ゲート 1 門と幅 $1.7 \mathrm{~m}$ の放流ゲート 1 門で新た に新設された。低地に位置するために藩政時代より洪水被害 を受けてきた「大堰」の改修・改良の歷史は、まさに諏訪湖 沿岸での水稻耕作への努力と洪水の歴史でもある。

3. 高島城建設と八ヶ岳山麓の開発

\section{（1）高島城建設}

高島城を築いた日根野織部正高吉は、織田信長や豊臣秀吉に 仕えた武将で、琵琶湖畔の安土城や淀川下流の大阪城築城に関 わった士技術者であった。1590(天正18) 年に2万8 千石の高島藩主となった日根野高吉は、城郭を湖中に張り出し 周囲に河川を巡らせ、低湿地を前面とした水城を計画した。 高島城建設工事の開始年代は諸説あって不明であるが、領主 が日根野氏から諏訪氏に替わった後の1598 (慶長3) 年に、 高島城が完成したと伝えられている。なお、日根野氏の諏訪支 配は約 10 年続いたが、7公3民と極めて過酷な年貢取り立て のため逃げ出宁農民が多く、田畑は䇠れていった。

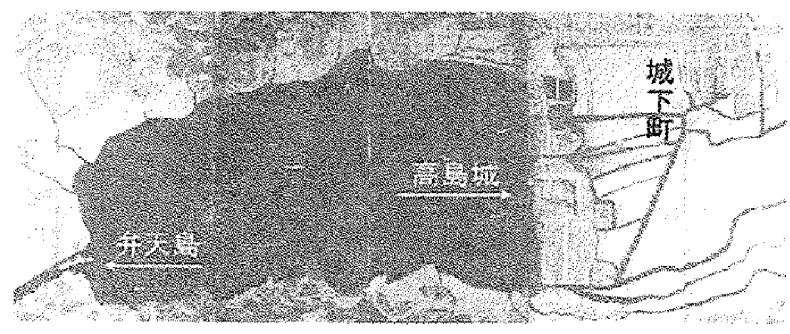

図一2 満水淈によって出来た弁天島と水城の高島城

(「御枕屏風、八剣神社所蔵」より一部複写・加筆)

関ケ原の戦い（1600）も収まり、諏訪氏の時代になると、世 の中が落ち着くにしたがい、禄を離れた浪人などが入植してき て、八ヶ岳山㭸や湖尻の開削によって干上がった低湿地帯 (阿 原）を開発して耕地を増していった。

高島城藩主 3 代目の諏訪忠治方政務を行う際に座右に置いて いた「御枕屏風」の絵図は、忠治が高島城完成から 66 年後の 1664 (寬文4）年に絵師に描力せている。同絵図には、諏 訪湖に面した高島城や城下町さらに諏訪湖に浮かぶ舟や現在の 
釜口水門付近に、後に述べる「満水堀」によって出来た弁天島 が描かれている。

（3）山麓の開田

近世の八ヶ岳山麓地域で最も開発が行われた所は、阿弥陀 岳と権現岳の間から流れる釜無川（富士川支川）支流の立場 川と北の八ヶ岳山簏一帯である。この八ヶ岳山麓は山浦（主 に現在の茅野市米沢等で、北八ヶ岳連峰と霧ヶ峰山塊の南端 に囲まれた地域の総称）と呼ばれていた。この山浦地方は、 水量の豊かな川が少なく、谷が深いので、標高の高、水源地付 近から新田開発が始まった。

1601 (慶長 6）年に初代藩主骤訪賴水（1570～1641） は、積極的に八ヶ岳山簏の溶岩台地の新田開発を奖励した。 その一例を原山新田（現原村）の開発（1610）に見ると、次 のような政策が取られている。

(1)年貢を一定期間免除する期間 (鍬下年期)を 4 年間とする。 (2)百姓役を免除する。

(3) 5 0町四方 (約 $30 \mathrm{Km}^{2}$ ) の林野を新田の草刈り場とする。 (4)武田信玄の軍事道路「上の棒道」を通行止めとする。

この様な政策が契機となって、山浦地方では灌溉用水を確保 しながら、1609（慶長14）年加1699（元禄12） 年の 90 年間に、 74 ケ所の新田が拓かれたと伝えられている。

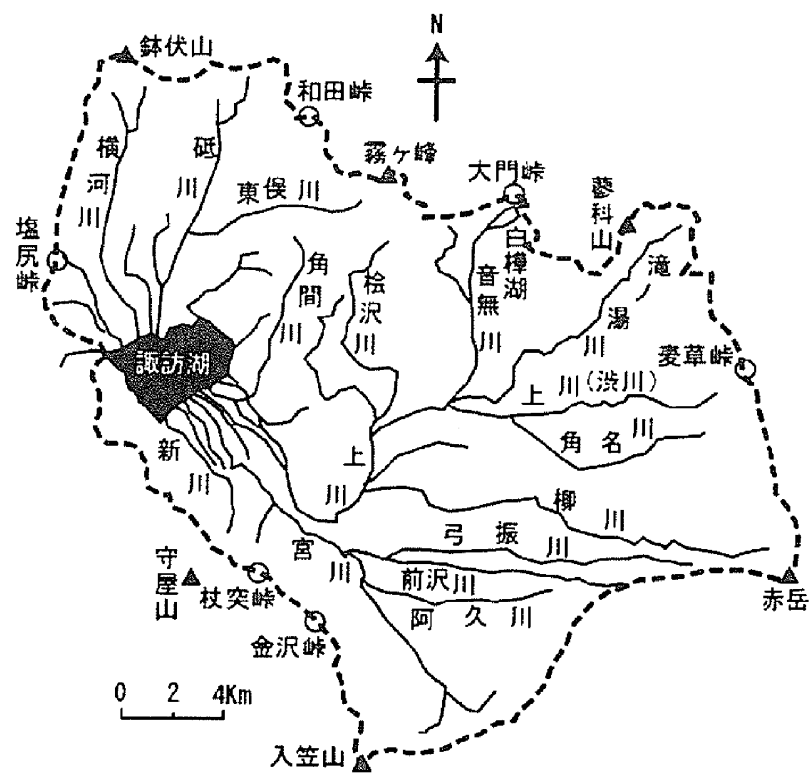

図－3 骤訪湖に流入している各支川（作成 : 久保田）

\section{4. 諏訪湖周辺の開発}

上述したように高島藩は主に茅野市、原村、富士見町の広大な 八ヶ岳西南山篗での新田開発に力を注いだ。一方、諤訪湖周辺 の低平地の開発は1 600 年代以前に、干拓開発の可能な所は すでこほほ開発が終了しており、1600年代から 100 年間 ほどの間に、小和田新田、諏訪市の低湿地の小川新田、角間川 扇状地の角間新田、下骤訪町の赤砂新田が開発されただけであ る。
諏訲湖に流入する河川は、本流と支川を合わせると 39 河川 になる。特に、霧ヶ峰南部功八ヶ岳の主流圭集める上川と、 南八ヶ岳の一部と南アルプス北端の入笠山以北の水を集める 宮川との合計流域面積は諏訪湖流域面積のほぼ半分を占めほ ど大きな流域で、昭和 58 年の出水で概観したように、これ らの川からの出水は大きく諏訪湖の汇濫に関係していた。

諏訪湖の南東部は、大小の支川が集中して流入しており、 この支川の扇状地上に成立した地域怯、阿原と呼ばれた湿地 帯であった。低湿地開発による阿原地域は天候に恵まれると 反当たりの収權量が一番良く藩の収入の $40 \%$ を占める款倉 地带であった。ところが一旦洪水が発生すると、支川からの 濁流々諏訪湖の汇濫によって阿原は、あっけなく水没する水

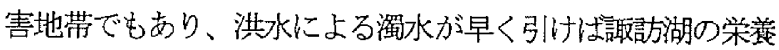
ある水が肥料となって収權が多く、一方、冠水期間が長い上 農作物水水腐れとなり、収和高が極めて不安定な土地柄であ った。したがって、この阿原地域の年貢はその年の出来高を 見て決めており、これらの土地を「見出」と言った。

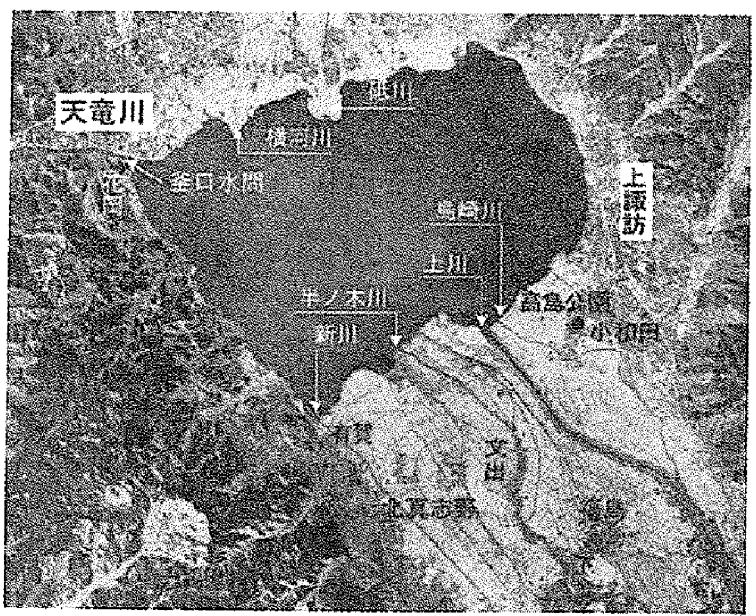

写真一 2 昭和 22 年の米軍による諏訪湖周辺の航空写 真（長野県諏訪建設事務所、『諏訪湖治水史の整史』の写 真に加筆)

この湿地帯を開拓した村々のうち、諏訪湖汇濫の被害をす ぐに受ける「見出六ヶ村」法小和田、文出、有賀、福島、下 金子、北真志野の6ヶ村であり、これらの村の後ろに位置す る、上諏訪、上桑原、下桑原、赤沼、中金子、田部、大熊、南 真志野の八ヶ村を加えて「天竜14ケ村」あるいは「天竜出 人村々」と呼ばれていた ${ }^{(3)}$

5. 湖尻の切り広め

（1）満水堀（天正堀）と新堀

高島城案城の際、諏訪湖加ら天竜川への流出口怯花岡村 (晲 岡谷市) 側であったが、諏訪湖の排水を改良するために、対岸 の下浜側に幅 4 間 $(7.2 \mathrm{~m})$ 、長さ 120 間 (216m) ほどの 1 本の排水路つまり「㳑水堀」(「天正堀」とも称される）と呼 ばれる排水路を開削したここの工事の開始年代は諸説あって不 
明であるが、領主が日根野氏か吅諏訪氏に替わった後の161

5 （元和元）年に完成したようである。

この「満水堀」工事によって、弁天島ができあがった（御 枕屏風参照)。その後さらに諏訪湖の水位を下げるために、1 683 (天和 3 ) 年〜 1689 (元禄 2) 年の問に、「新堀」 と名付けられた排水路を弁天島の中間に開削した。この工事 で排水路は3本（天竜川、新堀、满水堀）になり、下浜側の 面䅡約 30000 坪（1 今-3）の浜中島と浜中島よりやや小さく て長さ 60 間位 $(108 \mathrm{~m}) 、$ 幅 10 間位の花岡村側の弁天島と の 2 つ島になった (4)、(5)。

（2）伊藤五六郎による浜中島撤去とその後の弁天島 湖岸を開拓した湿地带は、1 171 (正徳元) 年〜182 8 (文政 1 1) 年の約 120 年間に、50回も浸水の大被害 を受けている。そこで、見出の「天竜14ケ村」は1829 （文政1 2）年に、伊藤五六郎が請願の中心人物となり、「天 竜釜口を切り広め、川岸の曲がりをなおし、釜口から下流の 駒沢の縩場までの川幅を広めるか、あるい怵浜から百間ほ と離れたところに満水掘をつくる」ことを藩の奉行所に訴え

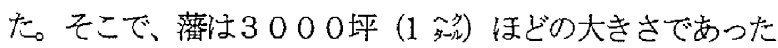
浜中島の撤去工事を弱冠 21 藏の五六郎に許可して、工事が 開始した。

\section{伊藤五六郎と浜中島}

五六郎は、諏訪郡豊田村有賀の農家伊藤尽之丞の長男とし て1809 (文化6) 年に生まれた。1828 (文政11) 年 の長雨で諏訪湖周辺一帯が水に浸かり、作物は水腐れとなり、

「竜 14 ケ村」は、「乍恐淎願上口上畫之事」を高自藩に提 出した。この頃の湖尻での天竜川の川幅䋇 $33 \mathrm{~m}$ で、現在 の川幅 $63 \mathrm{~m}$ のほぼ半分程度であった。

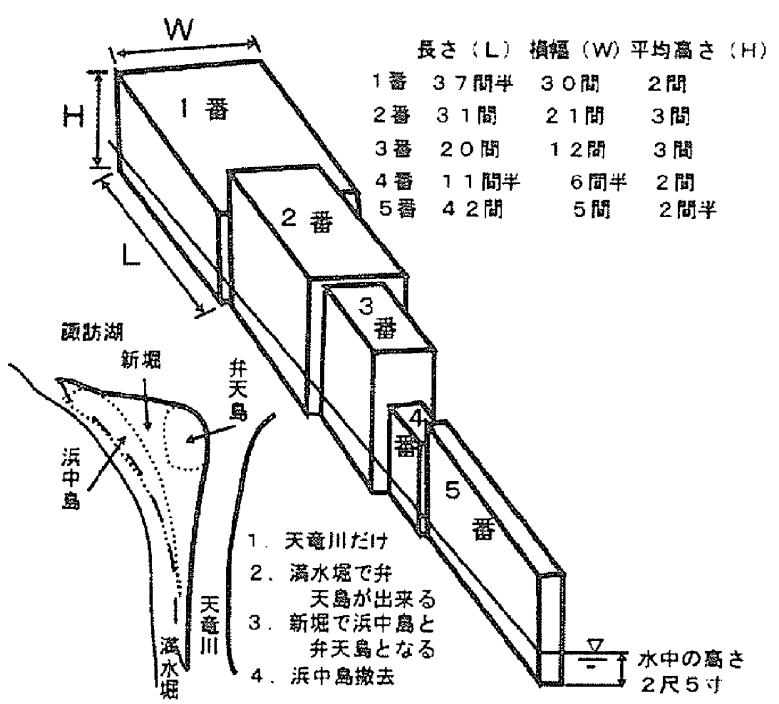

図-4 浜中島撤去の模式図と釜口の切り広図（作 成：久保田)
翌年、2 1 歳の五六郎は; 「面積の広い浜中島を5つに分割 して浜中島を撤去し、排水路の幅を広くする」計画を高島藩 一提出した。この計画採用され、1830 (文政13) 年加 ら、人足14546人、儥金注米 2 升 5 合、取り除心た土砂 は湖に捨てない条件で工事が開始された。

五六郎が1830（文政 13）年に藩に提出した「差上申御 請畫之事」の文を、骤訪青年会議所の資料 (6) を参考に模式図 を書くと、浜中島を5分割して、各部分の大きさと必要な人 足数京記述している。

平均の高さから水中の高さ（2 尺 5 寸) を引くと水際加 の高さとなり、各分割した体積と人足数は、1番で1327 $3 \mathrm{~m}^{3}$ で人足 4406 人、2番で $1151 \mathrm{~m}^{3}$ で人足 4118 人、3番で $4241 \mathrm{~m}^{3}$ で人足 1659 人、4番で $883 \mathrm{~m}^{3}$ で 3229 人、 5 番で $3078 \mathrm{~m}^{3}$ で人足 1134 人であり、 浜中島の合計体積は $32986 \mathrm{~m}^{3}$ であった。

諏訪青年会議所は創立 25 周年記念事業として、この五六 郎による浜中島撤去費用を仮設費、土工事費、運投費、捨土 整地費、環境整備費を試算して、約 2 億 1 千万円と試算して いる。

浜中島撤去工事で出た土砂は、諏訪湖で使われていた漁舟 の約 20 倍む大きい長さ $15 \mathrm{~m}$ 、幅 $3 \mathrm{~m}$ の大舟で湖を横切り、 高島城付近の有賀村の浅瀬入運び、ここを埋め立てて「五六

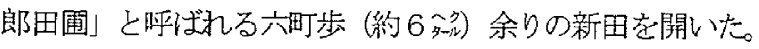
なお、利害の反する人々は、この土砂運搬に使用した大きな 舟を阿朵丸」と呼ひ朝り笑った。有賀には現在も六人ク夕

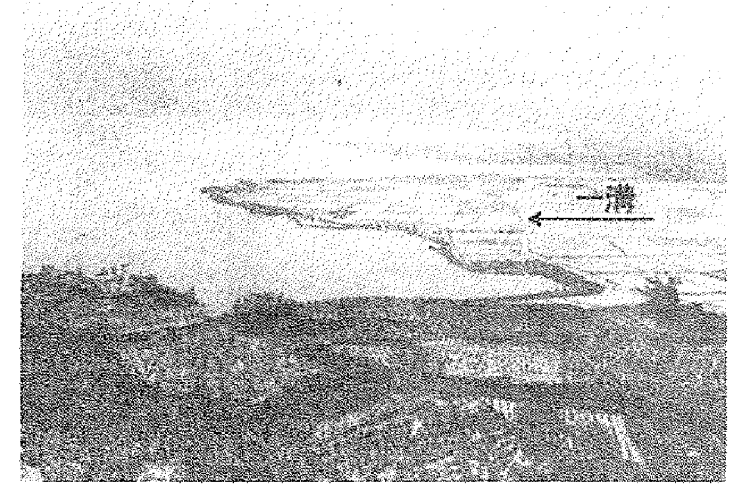

写真一 3 ほぼ三角形の「五六郎田圃」。「一溝」 ら湖面に突き出た三角形の土地が埋め立てた新田 ある。(『諏訪湖氾濫三百年史』より、 撮影年代不明)

一ル余りの「五六郎田固」が残っている。

五六郎は、害に偉大なる仕事を成し遂げたが、多額の借金 のため土地に居れなくなり、江戸へ出奔した。江戸でも不遇 であり、56歲の時、妻子を江戸に残して故郷の誀訪人帰鄉 して親類に身を寄せ、親類縁者から「厄介者」と嫌加れ、手 習いの師匠をして1868（明治元）年に他界した。 
伊藤五六郎の墓は、江音寺 (䃑訪市豊田有賀)の裏山の急傾 斜地にあり、自然石を反面削った墓石である。聲石の表に、法 岩了空信士 (五六郎の父) - 品明智員信女 (母) - 却外道永信士 (五六郎)」と刻まれて扣り、赛に文政 13 寅年7月 5 日・ 天保 9 戌年1 1 月 23 日・明治元戌辰 11 月 12 日」と刻まれ た簡素な墓であるが、付近の人々は今も「五六郎さん」と親し みを込めて呼んでいる。浜中島撤去後の釜口には弁天島が残り、 諏訪八景の1つに数えられ、葛飾北斎が「諏訪湖富士」の絵を 残している。

浜中島圶撤去してもな猢水の氾濫山止まず、1830 天 保元) 年〜1859（安政6）年までの30年間に19回の洪 水が記録されている。そこで、藩主諏訪忠誠が設置した目安箱 に、誰が入れたか不明であるが弁天島撤去の願い畫が入れられ、 1868 (明治元) 年の大洪水を契機に、弁天島は撤去された。

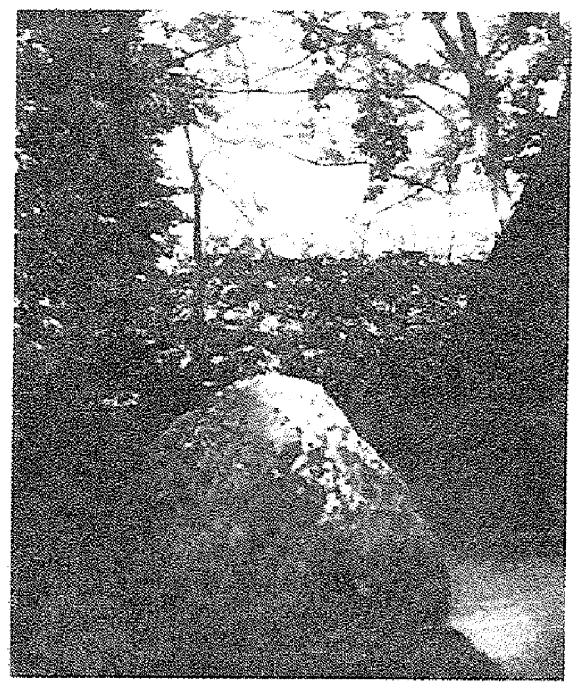

写真-4 ひっそりと急斜面に奉られ、有賀の五六郎 埔を見つめている五六郎の墓。（撮影：久保田、199 年7月16日)

\section{5. 諏訪湖浸水の主な原因}

(1) びったら橋

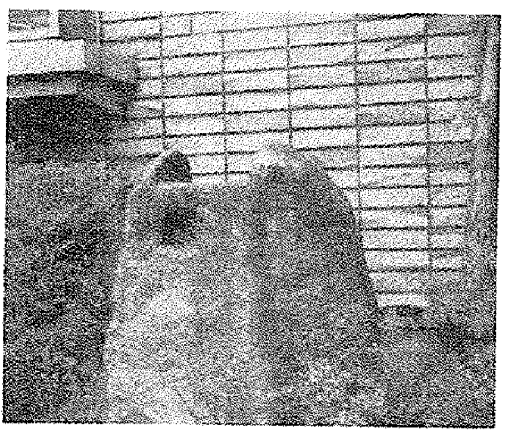

写真-5 下浜区民センター玄関 前に置かれた「びったら橋」の棉 台。(撮影：久保田、1997年 7 月 16 日)
江戸時代には、橋脚 は流水の流下を阻害 するので、湖尻での排 水に影響を与えない ように、諏訪湖の排水 の障害となる橋は建 設されず、「びったら 橋」が用いられた。

「びったら橋」は、上 部が回型に削られた 石の橋脚を多数川中 に並べこの石の上に

載せた板の片方を石にくくりつけた橋である。通行人が通ると 板が川面をぴたぴたと打ち鳴らすので「びったら橋」と名付け られた。高島藩では、春加ら秋の彼岸までこの橋圶架けること を禁じ、その間注舟を使用した。

ところが明治維新の混乱期に、現岡谷付近の村が、徂の許可 を受け、幅6尺 5 寸 (約 $2 \mathrm{~m}) 、$ 長さ 48 間 $(86.4 \mathrm{~m})$ 、橋脚が 1 1脚もある釜口橋を1874（明治7）年に1年弱で建設し た。その後、さらにこの橋架け替えられたが、橋脚が流水の 障害になっていることが認められ、1913（大正2）年に釜 口橋毦吊り橋となりようやく釜口橋問題は解決した。なお、び ったら橋の橋台位、現在下浜区民センターの玄関横と橋原区公 会所の庭に置か冯ている。

（2）製系用動力水車（藤車）と湛え

藩政時代、湖尻下流住民には梁の保諉と同様、藩は田用水 車 (藤車)に使用する藤蒸を藩の御林から無償で与え、一方、 水車による流水阻害を無くすために枝払いによる水車取り払 いの特権を上流住民に与えていた。主り、湖尻の上・下流住 民の利害が完全に対立していたので、藩はこの様に相反した政 策を取らざるを得なかったのである。

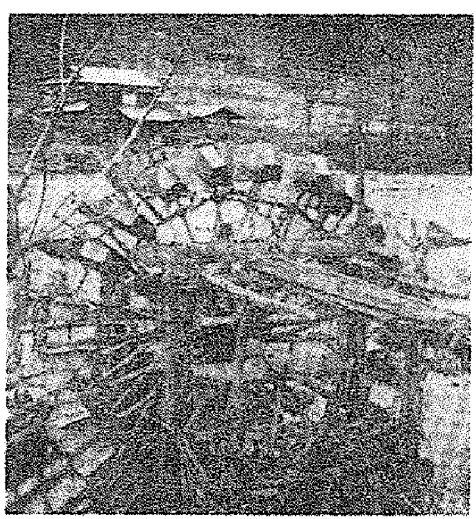

写真－6 田用水車 (藤車)、天竜 川の川岸村で使用されていた藤 車。（撮影：諏訪市民新聞社、昭 和 3 年、厄諏訪湖汇濫三百年史』 より)

き起こすのである。

さて動力水車と湛えについて触れよう。天竜川沿岸での製系 工場の数は、1877(明治10)年の5工場加ら 3 年後の1 880 年には43工場と急激に増吹し、1890年代には岡谷 製系工場が天竜川沿岸に集結した。

これら製系工場は動力源として「藤車」を改良した水車を用 いたが、規模は田用水車の比ではなかった。例穴ば、開明社の 水車は、水車幅 $2.4 \mathrm{~m}$ 、直径 $6.3 \mathrm{~m}$ 、羽根数 32 枚、湛えの 長さ43，2 mであった。

18.77 (明治 10 ）年代後半に、大洪水によって大被害を 
蒙った諏訪湖沿岸の農民は、製系工場の湛えおよひ動力用水車 の故去を強く望办、つ、1889(明治2 2) 年の大洪水の 際には実力で水車と湛えを切り流した。その後も、水車と湛え の設置と破壊が繰り返され、ようやく 1902 (明治3 5) 年 に、釜口量水標の水位によって湛えの長さを替えたり、取り払 う妥協案が提出された。ところが、これでも問題が解决せず、 1912 (明治 45 年、大正元年)、諏訪湖沿岸の農民は、浸 水被害面積一坪当たり一銭を製系会社側に支払って、天竜川の 流水を使用する動力用水車を電動に変更する様に要望した ${ }^{(7)}$ 。

靦在、骤訪市小和田の八剣神社内に、1914（大正 3) 年1 0 月の「排水記念碑」が建っている。この記念碑は、骤 訪湖の排水改良を記念して建てられたものである。1910

（明治43）、1911（同44）年と連続して発生した洪水 を契機に、1911年12月、天竜川排水期成同盟会が上讘 訪町高島公園に集まった被害者によって結成された。期成同 盟の強 希望と動力用水車它電動水車に取り替える補償金の 支払いと連動して、県は、1913（大正2）年秋から翌年 の春にかけて釜口橋を挟んだ天竜川川底を平均深さ $30 \mathrm{~cm}$ 浚渫する工事䘮行い、諏訪湖の平均水位を約 $24 \mathrm{~cm}$ 減少さ

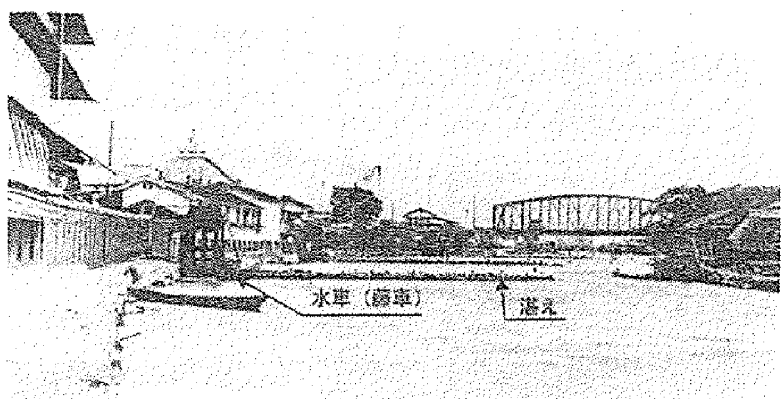

写真一7 天竜川の川幅の半分以上も出ている湛えと 水車 (藤車)。川を横切って長く湛えが出ており、この 湛えにより、流水の流下が阻害され堰上げされる。

(『骤訪湖治水の歴史』の写真に加筆)

せ、出水時におうける水位上昇もある程度は軽減された。これ を記念して、八剣神社内に記念碑が建てられたのである。

6. 湖岸の水害

\section{(1) 諏訪湖菱面積の変遷}

高島城が完成した約 45 年後の1642（寛永 $19 ）$ 年、 土橋七郎兵衛は諏訪湖両岸を見通した数ヶ所の直線距離を測 量して、骤訪湖の表面積を $27.797 \mathrm{Km}^{2}$ (2799 町 3 反) と記録している。この表面積の值は、現在の諏訪湖の面積が $13.30 \mathrm{Km}^{2}$ であり、諏訪湖に面していた水城の高島城周辺 が埋め立てられた事実を勘案しても、少々大きすぎる值の様 である。

ここでは、信頼のおける1911 (明治44) 年、 193 2 (昭和 7 ) 年、1949、1966、1972、1976 年の諏訪湖表面積を「諏訪湖汇濫三百年史」 ${ }^{(8)}$ と「諏訪湖治
水の歴史」 ${ }^{(9)}$ の資料より比較すると図一 5 の様になる。

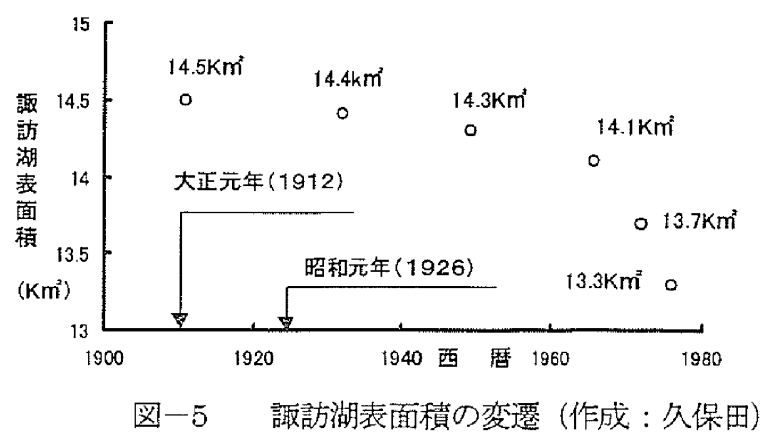

同図より、1911 (明治4 4) 年の1 $4.5 \mathrm{Km}^{2}$ 加占 19 76 (昭和 51 1) 年の1 $3.3 \mathrm{Km}^{2}$ まで、65年間で湖面積が 1. $2 \mathrm{Km}^{2}$ も減少している。土橋による 1642 （寛永 19 ） 年の表面䅡は少々大き方ぎて当時の面積は不明であるが、諏 訪湖の面積は、寛永年代 (1624～1643) 加ら1912（大正 元）年頃までの約 270 年間に相当埋め立てによって小さく なっていると推測される。つまり、江户時代から引き続き行 われてきた諏訪湖周辺の開発、および大きな出水の度に諏訪 湖人多量の土砂が流入して、諏訪湖の貯水容量は年每に減少 していったと考えられる。例えば、36炎時の出水によって 諏訪湖の 3 分の 1 に平均 $30 \mathrm{~cm}$ の厚さの土砂が堆積したと 報告されている。

同図より、1970年代頃に湖岸の整備と干拓によって大き く面積が減少している。この減少は、1969（昭和44）年 から 1980 年まで行われた第 1 期 (現在第 2 期浚渫工事が行 われている) 諏訲湖浚渫とその泥士による湖岸堤の背後地の埋 め立てに大きく影暨されており、また同時に、1973（昭和 48 ) 年に策定された天竜川工事実施計画に基つくく諏訪湖流入 支川整備や湖岸整備も影埅しているものと考えられる。

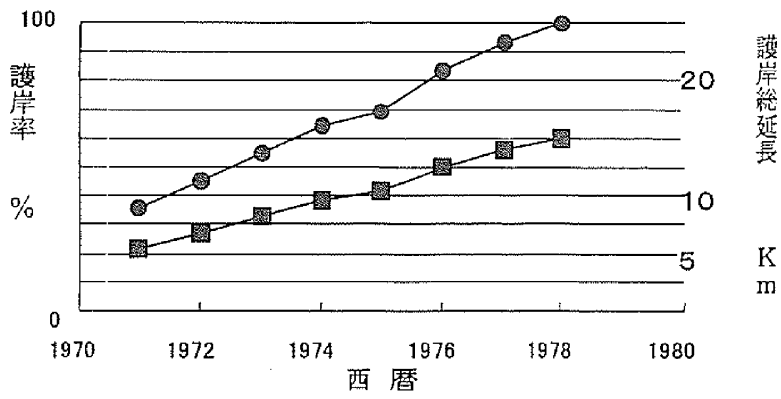

図-6『諏訪湖治水の歴史』より久保田が作成

図一6は、諏訪湖沿岸部での護岸工事の進路状況であり、1 971 (昭和 46) 年以前の護㞥総延長（圆印）は5 $351 \mathrm{~m}$ で護岸率 (ㅌ⼙) 約 $36 \%$ であるが、1978年には総延長は $14989 \mathrm{~m}$ (湖岸周囲長 $15860 \mathrm{~m}$ ) で護岸率もほぼ 10 ○\%に達している。 


\section{（2）明治以降の諏訪湖の氾濫}

1884 (明治 17 ) 年から初代釜口水門の建設が着工され る1932(昭和 7) 年までの釜口の量水標からの年最大浸水 面䆏、年間浸水回数および月別浸水回数注、諏訪湖氾濫三百年 史の資料 ${ }^{(10)}$ を図化すると図のようである。この時代、量水 標の水位 2 尺 $(60 \mathrm{c} \mathrm{m})$ が平水位で、2 尺を越えると浸水と 見なしている。同図の左側の縦軸が骤訪湖年最大浸水面積 $(\bigcirc$ 印、 $\mathrm{Km}^{2}$ )、右側の縦軸が各年で水位が 2 尺以上となった浸水 の回数（印）、同図の右上の図は、1884年加ら1932 年までの 49 年間で各月に発生した浸水の割合をパーセント で表している。

右上の棒グラフより、諏訪湖の汇濫は3月がら 10 月の間に 集中しており、特に田植えから稲刚りの期間に当たる5月から 9月が諏訪湖の汇濫期であり、水稲耕作に決定的な被害をもた らしている。

白丸匢の年最大浸水面積を見ると、1912 (大正元) 年頃 を境に、それ以降の浸水面積（白丸印）と浸水回数（黒丸印） が共に明治時代より減少している。この浸水面積の減少法、5 章で述べた製系動力用水車の撤去が大いに影響していると考 えられる。浸水回数示、明治時代には 1 年間に少なくて 7 回、 多、年は年12回每発生している。一方大正時代以降は、多い 年で年に 7 回、平均倠的に注ほぼ年3回の浸水回数に減少して おう、年に 1 度も浸水が発生していない年が 3 回も現れている。

なお釜口の量水標は、1883（明治16）年5月20日に 浜松の治水・治山家として有名な金原明善の治河協力社が諏訪 に建設したものであり、天童川で最も古い歴史を持つ量水標で あったここの量水標は釜口橋際の右岸に建設され、(1海抜75
$8.78 \mathrm{~m}$ がこの量水標の雾点であったが、昭和 11 年に釜口 水門が建設された後の零点は(2)海抜758.795 mと決定さ れ、付録で述べている1943（昭和18）年に計画された河 水統制事業そのもの恔実施されなかったが、1944年に統制 事業に関わる一連の工事が完了した後、水門管理規定の変更で 雺点は(3)海抜758.045 mに変更され、現在に至っている。

（3）西天竜一質水路取水堰

これまで見てきた様に、湖尻（釜口）を境として、諏訪湖 沿岸と下流域の人たちの利害は完全に相反していた。さらに 1922 (大正 11 ) 年に水不足の竜西側の人々が灌淮用水 を天竜川上流の岡谷市川岸から取水する計画つまり西天竜一 費水路取水殹建設を企てるにおよび、湖尻を境しした上・下 流域で水争いが頻発した。一方この取水堰建設問題注、天竜 川定挟んだ下流域の竜西側と竜東側との灌溉用水取得の争い をも発生させるのである。

1928 (昭和3）年 10 月に西天竜取水堰が完成した。 釜口を境とした上・下流域住民の紛争および下流域の竜西側 と竜東側との争いを解決するため、長野県は、1929 (昭 和 4) 年加ら諏訪湖治水・利水調查を開始した。1932（昭 和 7）年、罢任天童川上流改良工事として、釜口水門の設置 と諏訪湖に流入している支川改修工事を開始した。天童川本 川での改良工事では、河休を $1.8 \mathrm{~m}$ 掘り下げて流水能力を增 加させ、军口に設置する水門で湖水の水位を維持管理するこ ととした。なお竜川上流本川の改良工事は1937（昭和 12）年度まで継続された。

1932 (昭和 7) 年7月の洪水の際、釜口量水標の水位 は大汇濫を起こした 1923 (大正 12 ) 年7月の 5 尺3寸

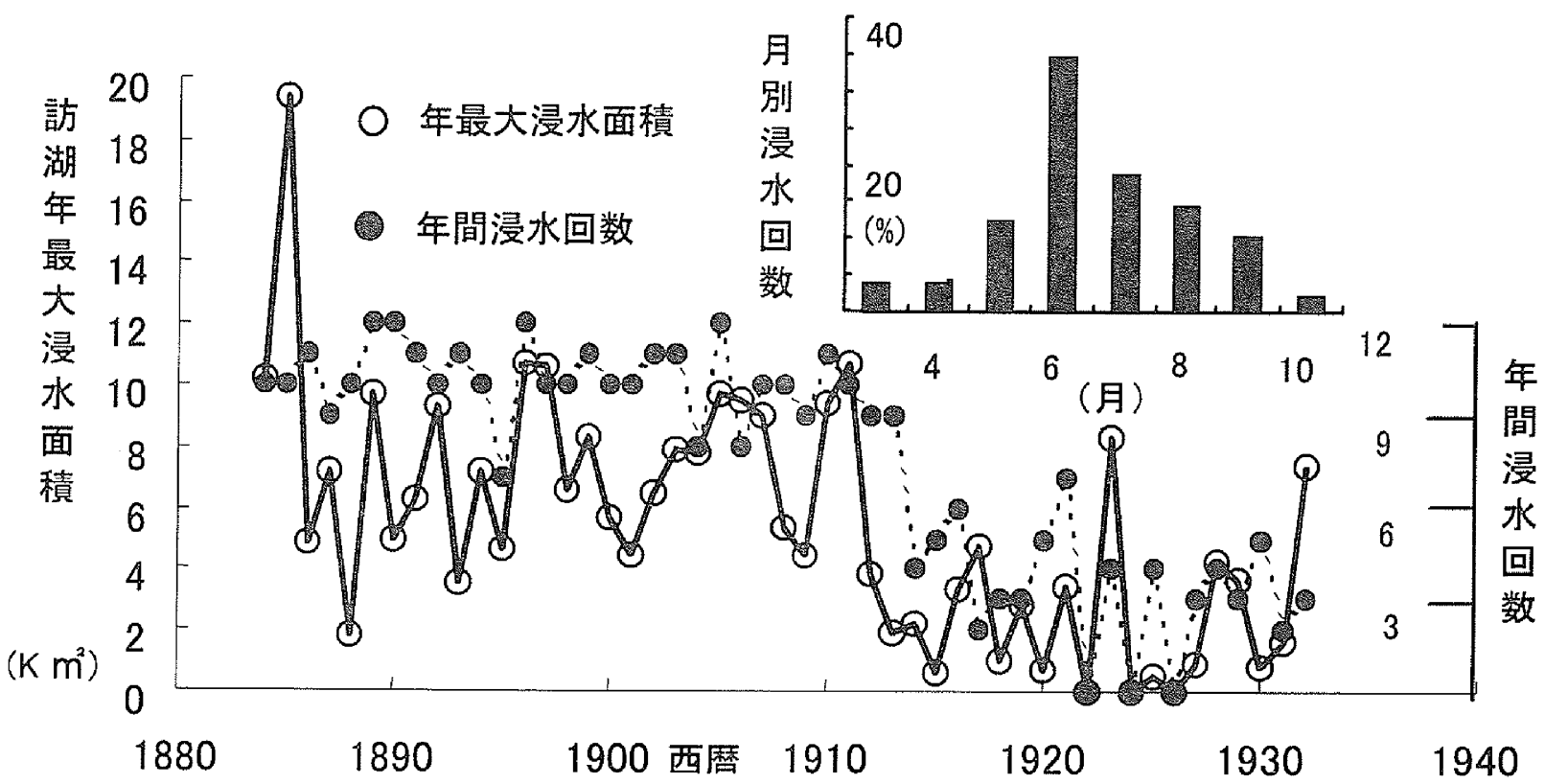

図一7 1884 年〜1932 年までの諏訪湖浸水の状況（『諏訪湖三百年史』より久保田が作成） 
8 分 $(1.61 \mathrm{~m})$ に次ぐ 5 尺 5 分 $(1.52 \mathrm{~m})$ に達し、大氾濫を 諏訪湖にもたらしたここの諁訪湖大浸水学契機に、天童川上 流改修事業（第 1 期改修工事）によって新川、碈川、横河川 等の改修や「諏訪湖治水組合」が発足して新たな時代に入っ た。この新たな出発のめざましい一歩が釜口水門の建設であ る。

\section{（4）釜口水門}

初代釜口水門は、骤訪湖の総合治水対策の一環として、1 932 (昭和 7) 年に着工して1936（昭和1 1) 年に完 成した。倳口水門は、幅 $7.3 \mathrm{~m}$ 、高さ $3 \mathrm{~m}$ の 7 つ水門を備 え、全開で195 $\mathrm{m}^{3} / \mathrm{s}$ を流出させ、湖面の水位を759. $2 \mathrm{~m} \sim 759.3 \mathrm{~m}$ を限度として調節することを目的とした 県直営の水門であり、水門の左右に幅 $4 \mathrm{~m}$ 魚道と舟道を備 えていた。

釜口水門完成の翌年、釜口水門管理規定が策定された。水 門管理については、県と浸水被呈を受ける諏訪湖住民が組織 した「諏訪湖治水組合」との間で話し合いがもたれ、結局、 県が釜口水門を管理することとなった。

初代釜口水門の老朽化に伴い、1978（昭和53）年に旧 水門の約 $80 \mathrm{~m}$ 上流に 2 代目釜口水門の建設が計画され、19 88 年に完成した。新しい水門は、3つの水門と左岸則に舟道、 右岸側に魚道を備え、諏訪湖人の計画流入量 $1600 \mathrm{~m}^{3} / \mathrm{s}$ のうち最大放流量 $600 \mathrm{~m}^{3} / \mathrm{s}$ (釜口下流の流下能力不足の ために暫定的に $300 \mathrm{~m}^{3} / \mathrm{s}$ ）の水門である。

\section{7、おわりに}

釜口水門の建設経過恀くの本ですでに紹介されている。

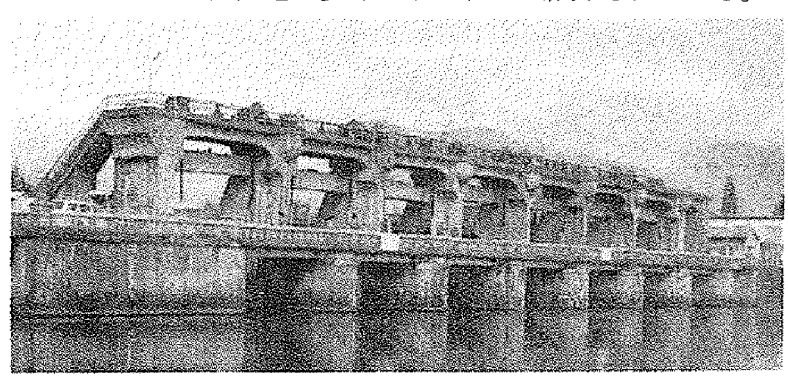

写真-8 昭和 5 3年当時の旧釜口水門。写真をよく見る と、堹柱等に無数のクラック（ひひ割れ）が現れている。 (九津見撮影)

かし建設に至った湖尻を境とした上・下流住民の闘い、その時 代の要請により、むしろ被害者である浸水被害住民が加害者の 立場の会社に動力電源に切り替えるための補償金を支払って
いた事実とこの補償問題を境に浸水被害が激减した事実、また、 諏訪湖湖面面䅡の湖岸埋め立てによる減少、等は記録しておく 必要が有ると考えている。

著者等は、この様な観点からこの一文を記した。今後は、諏 訪湖の水質にも目を向け、先人達が苦労して築き、守ってきた 諏訪湖度「きれいな環境」で将来に残す努力をするときである 5 。

付録：河水統制事業

河水統制事業法、水系一頁して洪水処理計画を確立してタ 等の貯留水の高度利用を図る目的で、1937（昭和 1 2) 年に河水統制調查費が承認され、利根川を始め16水系につ いて1950（昭和2 5) 年度まで河水統制調查が行われた。

天竜川の源諏訪湖でも、戦時中の電力と食糧不足を補うた め、1943（昭和18）年9月に諏訪湖を一大貯水池とし て使用する「諏訪湖河水統制計画」が発表された。この計画 は、釜口水門による湖面利用水深を従来の $30 \mathrm{~cm}$ 分ら90 $\mathrm{cm}$ と大きくして諏訪湖の有効貯水量を 1296 万 $\mathrm{m}^{3}$ に增 加させ、従来の最小流出量を適時 2 倍から 3 倍に上げ、 1 日 当りの放流量約 $2380 \mathrm{~m}^{3}$-゙天竜川下流の大久保、南向、泰 阜および平岡発電所の電力を5００万キロワット増加させ、 さらに1日当り放流量約 $590 \mathrm{~m}^{3}$ で下流域 1, 550 町歩 （約 1540 多-名）の灌激用水不足を解消して、米を 2,300 石 増産する計画であった。

参考文献

（1）長野県建設技術センター、『諏訪湖治水の歴史小、長野 県諏訪建設事務所、1 $22-127$, 平成 10 年。

（2）諏訪市史編管委員会、『諏訪市史 (下巻)』、諏訪市役所、 $225-227$, 昭和 51 年。

（3）諏訪市史編箱委員会、『諏訪市史 (中巻)』、諏訪市役所、 $678-693$, 昭和 63 年。

（4）北原優美、『諏訪湖一汇濫の社会史一』、天竜川上流工 事事務所、1 $12-14$ 、平成 5 年

（5）建設省天龍工事事務所、『大龍川凟料小、156-17 9 , 昭和 30 年代

（6）25周年特別委員会、『年創造の時代小、社団法人諏 訪青年会議所、73-83，1992年。

(7) 岡谷市、『岡谷市史』、岡谷市役所、 $260-262$, 昭和 48 年。

（8）堀江二五郎、『骤訪湖汇濫三百年史 (諏訪湖汇濫史干师 会複製)、鄉土出版社、664-665、1985 年。

（9）長野影建設技術センター、『諏訪湖治水の歷史』、長野 県骤訪建設事務所、234, 平成 10 年。

（1０）堀江三五郎、『諏訪湖汇濫三百年史 (諏訪湖汇濫史 刊行会複製)』、郷土出版社、654-66 O、198 5 年。 